Original Research Article

\title{
Evaluation of antiulcer activity of ethanolic leaf extract of Coccinia grandis in indomethacin induced gastric ulcer model
}

\author{
Barathane Datchanamurty ${ }^{1 *}$, Mythireyi D. ${ }^{2}$, Divyashanthi C. M. ${ }^{3}$
}

${ }^{1}$ Department of Pharmacology, Mahatma Gandhi Medical College and Research Institute, Sri Balaji Vidyapeeth, Pillaiyarkuppam, Puducherry, India

${ }^{2}$ Government Peripheral

Hospital, Tondiarpet, Chennai, Tamil Nadu, India

${ }^{3}$ Department of Pharmacology, Vinayaka Missions Medical College, Vinayaka Missions Research Foundation, Karaikal, Pondicherry, India

Received: 04 February 2019 Accepted: 08 March 2019

\section{*Correspondence to:}

Dr. Barathane Datchanamurthy, Email: barathane20@gmail.com

Copyright: (C) the author(s), publisher and licensee Medip Academy. This is an openaccess article distributed under the terms of the Creative Commons Attribution NonCommercial License, which permits unrestricted noncommercial use, distribution, and reproduction in any medium, provided the original work is properly cited.

\begin{abstract}
Background: Gastric mucosal ulceration is the most common adverse effect with NSAIDS. Antacids, $\mathrm{H} 2$ blockers and PPIs are considered novel in treating ulcers but are not devoid of side effects. Hence, there a need for a drug which is effective against NSAID induced ulcers with no side effects. Coccinia grandis plant is traditionally used for the treatment of gastric/peptic ulcers. Hence, this study has been undertaken to scientifically validate the antiulcer activity of Coccinia grandis leaves against indomethacin induced gastric ulcer model.

Methods: Following preparation of the extract, $24 \mathrm{Wistar}$ rats were divided into 4 groups with 6 rats in each group $(n=6)$. Group 1 received 1\% CMC, group 2 received $1 \% \mathrm{CMC}$ +indomethacin $40 \mathrm{mg} / \mathrm{kg}$, group 3 received ethanolic leaf extract of Coccinia grandis $200 \mathrm{mg} / \mathrm{kg}$ +indomethacin $40 \mathrm{mg} / \mathrm{kg}$ and group 4 received omeprazole $(2 \mathrm{mg} / \mathrm{kg})+$ indomethzacin $40 \mathrm{mg} / \mathrm{kg}$ for 7 days. Calculation of ulcer score was done using ulcer index and percentage protection.

Results: The ulcer index score $(2.12 \pm 0.21)$ and percentage protection $(69.71 \%)$ was comparable with the standard drug $(1.76 \pm 0.11,74.85 \%)$ respectively.

Conclusions: The ethanolic leaf extract of Coccinia grandis showed significant antiulcer activity against indomethacin-induced gastric ulcer. Further studies are warranted to elucidate the exact mechanism of antiulcer activity.
\end{abstract}

Keywords: Coccinia grandis, Ethanolic extract, Gastric ulcer, Indomethacin, Omeprazole, Ulcer index

\section{INTRODUCTION}

Peptic ulcer is the most common gastrointestinal disorder characterized by deep erosions involving the entire mucosal thickness leading to a perforation in extreme cases. Since, the time it was believed that the pathogenesis is due to excess secretion of gastric acid. ${ }^{1}$ Off late, due to continuous research, it has now been established that peptic ulcer disease is due to the imbalance between aggressive and defensive factors which interplay in maintaining the mucosal integrity. ${ }^{2,3}$

Aggressive factors such as smoking, stress, lipid-rich diet, alcohol, NSAID's and $\mathrm{H}$. pylori infections may trigger 
mucosal ischemia and erosions by overcoming host defense mechanisms such as mucus and bicarbonate secretion. $^{4}$

The latest approach for the treatment of peptic ulcer disease is by reducing acid secretion and restoring gastric mucosal protection. The knowledge of peptic ulcer disease and its pathogenesis has put forth the development of a variety of drugs like PPI's, H2 blockers, acid neutralizing agents etc in counteracting the disease process and restoring the balance. As with any chemical substance on chronic use may produce several adverse reactions, decreased efficacy and toxicity, the search for a natural and safer alternative especially those derived from plants is ongoing. ${ }^{5}$

Plant extracts are some of the most attractive sources of new drugs and have been shown to produce promising results for the treatment of gastric ulcer.

Coccinia grandis (C. grandis) also known as ivy gourd, family Cucurbitaceae is a tropical climber, native to Africa and Asia. Parts of the plant such as its leaves and fruits are consumed as vegetables in the southeast Asian regions. The plant has been explored for its hypoglycemic, antibacterial, anti-inflammatory, antipyretic, analgesic, antifungal, hepatoprotective and antioxidant property with success. ${ }^{6}$ Although many of its biological properties have been exploited, pharmacological data regarding its actions on the gastrointestinal system is still inconclusive. Thus, in this study, an attempt has been made to evaluate the antiulcer activity of the ethanolic leaf extract of $C$. grandis on indomethacin-induced ulcer models.

\section{METHODS}

\section{Collection and identification of plant materials}

The leaves of Coccinia grandis were collected fresh from the rural areas of Pondicherry, India and was authenticated by a local botanist from science college. The leaves weighing $4 \mathrm{~kg}$ were cleaned, shade dried and pulverized using an electric grinder. They were stored in airtight containers at room temperature.

\section{Preparation of the extract}

Ethanolic extract was prepared as per the procedure elaborated by Mahanta M et al. ${ }^{7} 40 \mathrm{~g}$ of dried powder was weighed and packed in the thimble of Soxhlet apparatus (Borosil) and extraction was carried out continuously with $150 \mathrm{ml}$ of $95 \%$ ethanol refluxing at $50-70^{\circ} \mathrm{C}$. The extract was concentrated and died using an oven at $45^{\circ} \mathrm{C}$ for 24 hours. The stock powder was stored in a glass desiccator at $4^{\circ} \mathrm{C}$. The total yield per cycle was around $22 \%(\sim 9.9 \mathrm{~g})$.

\section{Chemicals}

Ethanol and carboxy-methylcellulose (CMC) were procured from SD fine chemicals, Mumbai, Maharashtra,
India. Omeprazole and indomethacin were procured from a local medical store.

\section{Ethical clearance}

Ethical clearance was taken from Institutional Animal Ethics Committee of the institute before the commencement of the study.

\section{Animals}

Adult male Wistar rats $10-12$ weeks of age weighing $180 \pm 20 \mathrm{~g}$ were procured from King's Institute, Guindy, Chennai, Tamil Nadu, India. They were housed and maintained in the central animal house of the institute two weeks prior to the commencement of the study so that they could adapt to the new environment. Animals were kept in polypropylene cages with dry paddy husk bedding maintaining a room temperature of $26 \pm 2^{\circ}$ and relative humidity of $45-55 \%$ with 12:12 hour dark and light cycle. They were fed with standard pellet diet and water ad libitum. Care of the animals in the central animal house in accordance with the guidelines suggested by Committee for the Purpose of Control and Supervision of Experiments on Animals, New Delhi, India. ${ }^{8}$

\section{Acute toxicity testing}

Healthy adult male Wistar rats were used for this study. A pilot study was carried out according to OECD guidelines and a limit dose of $2000 \mathrm{mg} / \mathrm{kg}$ was found to be safe. The animals were observed continuously for 4 hours and then occasionally for further 4 hours and finally overnight. Animals were observed for tremors, clonic convulsions, tonic extensions, catatonia, spasticity, opisthotonus, ataxia, sedation, ptosis, respiration. The animals were continuously observed for 24 and 72 hours for any lethality or death.

\section{Dose selection}

As the limit dose didn't exhibit any signs of toxicity, a dose of $200 \mathrm{mg} / \mathrm{kg}$ which was $1 / 10 \mathrm{~h}$ of the limit dose $(2000$ $\mathrm{mg} / \mathrm{kg}$ ) was taken up for the main study. Omeprazole and indomethacin were used at $2 \mathrm{mg} / \mathrm{kg}$ and $40 \mathrm{mg} / \mathrm{kg}$ respectively.

\section{Experimental design}

24 healthy adult Wistar albino rats weighing $180 \pm 20 \mathrm{~g}$ were used in the study. The total duration of the study was for 1 week. After acclimatization, the rats were divided into 4 groups with 6 rats in each group $(n=6)$. The rats were numbered and grouped based on random numbers generated using computer software.

Group 1 (normal control) was treated with the vehicle CMC 1\%. Group 2 (positive control) was treated with indomethacin $40 \mathrm{mg} / \mathrm{kg}$. Group 3 (test group) was treated with ethanolic leaf extract of Coccinia grandis (ELECG) 
at $200 \mathrm{mg} / \mathrm{kg}$ along with indomethacin at $40 \mathrm{mg} / \mathrm{kg}$. Group 4 (standard group) was treated with omeprazole $2 \mathrm{mg} / \mathrm{kg}$ along with indomethacin $40 \mathrm{mg} / \mathrm{kg}$. all the chemicals and extract were suspended in 1\% CMC and administered using a gavage needle (Table 1 ).

Table 1: Experimental design.

\begin{tabular}{|lll|}
\hline $\begin{array}{l}\text { Study } \\
\text { groups } \\
\text { n=6 }\end{array}$ & Type & Treated with \\
\hline Group 1 & Normal control & $1 \% \mathrm{CMC}$ \\
\hline Group 2 & Positive control & $\begin{array}{l}1 \% \mathrm{CMC}+\text { indomethacin } \\
40 \mathrm{mg} / \mathrm{kg}\end{array}$ \\
\hline Group 3 & Test group & $\begin{array}{l}\text { ELECG } 200 \mathrm{mg} / \mathrm{kg}+ \\
\text { indomethacin } 40 \mathrm{mg} / \mathrm{kg}\end{array}$ \\
\hline Group 4 & Standard group & $\begin{array}{l}\text { Omeprazole }(2 \mathrm{mg} / \mathrm{kg}) \\
\text { +indomethacin } 40 \mathrm{mg} / \mathrm{kg}\end{array}$ \\
\hline $\begin{array}{l}\text { CMC-Carboxymethylcellulose, ELECG-Ethanolic leaf extract of } \\
\text { Coccinia grandis. }\end{array}$
\end{tabular}

The drugs, as well as the extract, were administered orally between 9-10 am for 7 days. On the $7^{\text {th }}$ day, 6 hours after the last administration of the drugs, rats were sacrificed by an overdose of sodium pentobarbital $150 \mathrm{mg}$ I.P. The stomach was dissected out along the greater curvature and examined for lesions. The mucosa was then washed, and extent of ulceration was scored as per the method suggested by Kunchandy $\mathrm{J}$ et al. ${ }^{9}$ Bits of tissue were sent for histopathological examination. The gastric mucosa was examined using a magnifying lens $(3 \mathrm{x})$ for any visible mucosal damage. Hemorrhagic spots greater than $2 \mathrm{~mm}$ diameter was taken as ulcers.

\section{According to the following scale}

- $0=$ Normal grey colored stomach,

- $0.5=$ Pink to red coloration of the stomach,

- $1=$ Spot ulcer,

- $1.5=$ Hemorrhagic streak,

- $2=$ Number of ulcers $<5$,

- $3=$ Number of ulcers $>5$,

- $\quad 4=$ Ulcer with bleeding.

Ulcer index was calculated using formula,

Ulcer Index $=10 / X$

Where, $\mathrm{X}=($ Total mucosal area $) /($ total ulcerated area $)$.

Percentage ulcer protection $=($ Ulcer index of positive control-ulcer index of test group)/(ulcer index of positive control)x 100 .

\section{Estimation of TBARS, SOD, Catalase, and GSH}

There was $1 \mathrm{gm}$ of gastric tissue got homogenized in 50 $\mathrm{mM}$ phosphate buffer at a $\mathrm{pH} 7.2$ using a glass-teflon homogenizer. During the process, the temperature was kept cold using a water bath filled with ice. The homogenate was later centrifuged at $2500 \mathrm{rpm}$ for $10 \mathrm{~min}$, and the supernatant was carefully pipetted out and stored at $-20^{\circ} \mathrm{C}$ until further analysis.

The antioxidant action of the ELECG was estimated by measuring the thio-barbituric acid reactive substances (TBARS), superoxide dismutase (SOD), glutathione (GSH) and catalase activity in the tissues. ${ }^{10-13}$

\section{Statistical analysis}

Data collected were entered in Microsoft Excel 2013 and analysed using SPSS v.17. Results were expressed in Mean \pm SEM as tables. Statistical analysis was done using One-way ANOVA followed by Students unpaired ' $t$ ' test. A p-value $<0.05$ was considered as statistically significant at $95 \%$ confidence interval.

\section{RESULTS}

\section{Acute toxicity study of ethanolic leaf extract of Coccinia grandis}

Acute toxicity studies confirmed the ethanolic leaf extract of Coccinia grandis up to a dose of $2000 \mathrm{mg} / \mathrm{kg}$ body weight was non-toxic. No death was observed for up to 72 hours. There was no lethality, or any toxic reactions found at any of the doses selected until the end of the study.

\section{Phytochemical analysis}

Preliminary analysis of the extract revealed the presence of flavonoids, terpenoids, phenols, tannins, cardiac glycosides, carbohydrates, saponins, phloba-tannins, sterols and some amino acids like arginine. asparagine, glutamine, threonine, glycine, proline (Table 2).

Table 2: Phytochemical constituents of ethanolic leaf extract of Coccinia grandis.

\begin{tabular}{|ll|}
\hline Phytoconstituents & $\begin{array}{l}\text { Ethanolic leaf extract } \\
\text { of Coccinia grandis }\end{array}$ \\
\hline Flavonoids & ++ \\
\hline Tannins & + \\
\hline Alkaloids & + \\
\hline Carbohydrates & + \\
\hline Glycosides & + \\
\hline Terpenoids & + \\
\hline Phenols & - \\
\hline Phytosterols & + \\
\hline Fixed oils and fat & - \\
\hline Phlobatannins & + \\
\hline Volatile Oils & - \\
\hline Protein and amino acid & + \\
\hline Saponins & + \\
\hline Coumarins & - \\
\hline
\end{tabular}


Table 3: Effect of ethanolic leaf extract of Coccinia grandis on ulcer index and percentage inhibition.

\begin{tabular}{|c|c|c|c|}
\hline \multicolumn{2}{|l|}{ Treatment $(n=6)$} & Ulcer index & $\begin{array}{l}\% \\
\text { inhibition }\end{array}$ \\
\hline $\begin{array}{l}\text { Group } 1 \\
\text { Normal control }\end{array}$ & $\mathrm{CMC}$ & $0.83 \pm 0.25$ & - \\
\hline $\begin{array}{l}\text { Group } 2 \\
\text { Positive control }\end{array}$ & $\begin{array}{l}\text { CMC } \\
+ \text { IND }\end{array}$ & $7.0 \pm 1.6^{*}$ & - \\
\hline $\begin{array}{l}\text { Group } 3 \\
\text { Test group }\end{array}$ & $\begin{array}{l}\text { ELECG } \\
+ \text { IND }\end{array}$ & $2.12 \pm 0.21 * *$ & 69.71 \\
\hline $\begin{array}{l}\text { Group } 4 \\
\text { Standard group }\end{array}$ & $\begin{array}{l}\text { OME } \\
+ \text { IND }\end{array}$ & $1.76 \pm 0.11 * *$ & 74.85 \\
\hline
\end{tabular}

\section{Effect of Ethanolic leaf extract of Coccinia grandis on gastric mucosa}

The positive control group treated with indomethacin alone produced significant mucosal erosions with occasional bleeding resulting in increased ulcer index score.
The group pre-treated with standard drug omeprazole (group 4) and the group pre-treated with extract of Coccinia grandis (group 3) showed a significant decrease ( $\mathrm{p}<0.001)$ in ulcer index when compared to the positive control group (group 2). Percentage inhibition of ulcers for group pre-treated with extract of Coccinia grandis (group 3) was comparable with that of the standard group (Table 3).

\section{Effect of ethanolic leaf extract of Coccinia grandis on TBARS and antioxidant levels}

In the positive control group, there was a marked increase in the TBARS and a significant decrease in antioxidant levels was observed. Administration of ELECG at 200 $\mathrm{mg} / \mathrm{kg}$ significantly reduced the TBARS level which is comparable with that of standard drug. The SOD, GSH and catalase activity in the gastric tissues were significantly lower in the positive control group when compared to normal. Treatment with the leaf extract has significantly improved the levels of GSH and catalase activity but less compared to the standard group. SOD levels were significantly better than the standard control with rats pretreated with the extract (Table 4).

Table 4: Effect of ethanolic leaf extract of Coccinia grandis on TBARS and other antioxidant levels.

\begin{tabular}{|llllll|}
\hline Treatment $(\mathbf{n}=\mathbf{6})$ & & SOD IU/g tissue & Catalase IU/g tissue & GSH $\mu \mathrm{g} / \mathrm{mg}$ tissue & TBARS nmol/g tissue \\
\hline Normal control & CMC & $61.32 \pm 7.8$ & $134 \pm 10.2$ & $3.2 \pm 0.5$ & $0.42 \pm 0.02$ \\
\hline Positive control & CMC+IND & $23.42 \pm 5.2$ & $62 \pm 12.3$ & $1.1 \pm 0.39$ & $1.3 \pm 2.17$ \\
\hline Test group & ELECG+IND & $89.18 \pm 11.2^{*}$ & $123 \pm 19.2^{*}$ & $2.7 \pm 0.45^{*}$ & $0.63 \pm 5.26^{*}$ \\
\hline Standard control & OME+IND & $76.14 \pm 10.1^{*}$ & $125 \pm 10.7^{*}$ & $3.0 \pm 0.35^{*}$ & $0.70 \pm 3.88^{*}$ \\
\hline
\end{tabular}

Data expressed as Mean \pm SEM. $(\mathrm{n}=6)$ in each group. *Significant $\mathrm{P}$ value $(<0.05)$ with One-way ANOVA followed by post hoc Bonferroni test when compared with positive control. SEM-Standard error of mean. CMC-Carboxymethylcellulose, ELECG-Ethanolic leaf extract of Coccinia grandis at 200 mg/kg. IND-Indomethacin, OME-Omeprazole, SOD-Superoxide dismutase, GSH-Reduced glutathione, TBARS-Thiobarbituric Acid Reactive Substances.

\section{Effect of ethanolic leaf extract of Coccinia grandis on gastric mucosal histopathology}

Histology of gastric mucosal sections of normal control exhibited normal gastric mucosa with no disruption in the mucosal integrity (Figure 1A).

The positive control treated with indomethacin alone showed extensive mucosal ulceration, necrosis and extensive leucocytic infiltration (Figure 1B).

The group pre-treated with ELECG showed reduced signs of inflammation and significant mucosal regeneration which is comparable to that of the standard group (Figure $1 \mathrm{C)}$.

The standard group treated with omeprazole showed a near normal picture and there were no significant changes when compared to normal control (Figure 1D).

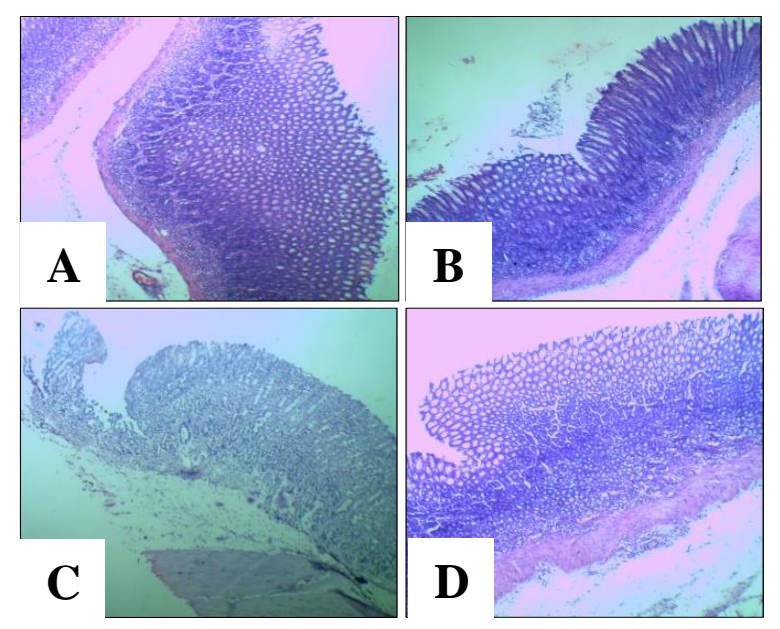

Figure 1: Effect of Ethanolic leaf extract of Coccinia grandis on gastric mucosal histopathology. A) Normal control, B) Positive control, C) ELECG at $200 \mathrm{mg} / \mathrm{kg}$, D) Standard control. 


\section{DISCUSSION}

The study showed the antiulcer activity of Coccinia grandis leaves against indomethacin-induced gastric ulcer models.

NSAID's are the most common OTC drugs which are used extensively for all types of pain. Indomethacin is a nonselective COX inhibitor, inhibits the arachidonic acid pathway and the formation of protective prostaglandins. ${ }^{14}$

Prostaglandins especially PGE2 and PGI2 are antiulcerogenic and they play a crucial role in gastric mucus secretion and mucosal blood flow. ${ }^{15}$ Apart from that NSAID's also inhibit mucosal cell proliferation and bicarbonate secretion thereby greatly reducing the integrity of the gastric mucosa. ${ }^{16}$

Administration of indomethacin in test groups produced significant visible gastric erosions, bleeding and necrosis thereby increasing the ulcer index score. Groups pretreated with Coccinia grandis leaf extracts showed a significant reduction in the intensity of gastric lesions, and ulcer index score.

Present study findings were inconsistent with previous studies conducted by Manoharan P et al, who suggested that leaf extract of Coccinia grandis possessed significant antiulcer activity against pyloric ligation model. ${ }^{17}$ Similar studies conducted by Girish C et al, and Santharam B et al, also confirmed that ethanolic and aqueous extract of Coccinia grandis leaves attenuated gastric ulcer formation by reducing the gastric volume and total acidity. ${ }^{18,19}$ In addition to that leaf extract also have attenuated the inhibitory effect of indomethacin over the secretion of protective prostaglandins thereby promoting mucus formation and ulcer healing which is evident by the decrease in ulcer index score.

Peptic ulcer induced by NSAIDs is not only dependent on the inhibition of prostaglandins but also due to the damage caused by the generation of free radicals. Free radicals markedly deplete the innate antioxidants like SOD, catalase and GSH which are the first inline defense against cellular damage. ${ }^{20}$ Reduction in cellular antioxidants and increase in tissue MDA strongly suggests an ongoing free radical damage.

In present study, pre-treatment with the leaf extract of Coccinia grandis for 7 days significantly increased the levels of SOD, catalase and GSH with a concurrent decrease in TBARS level suggestive of its potential antioxidant action.The histopathological findings were consistent with the gross examination and scoring. Groups pre-treated with ELECG showed significant improvement in mucosal integrity, re-epithelization and reduced inflammatory infiltrates, which confirms the antiulcer and cytoprotective effect of the extract.

\section{CONCLUSION}

To conclude, the ethanolic leaf extract of Coccinia grandis exhibited significant antiulcer and antioxidant activity against indomethacin-induced gastric ulcer models. The extract offered significant mucosal protection by reducing the ulcer index which may be due to the presence of flavonoids. Further research should be conducted to identify the active principle before human use.

\section{ACKNOWLEDGEMENTS}

Authors would like to thank Dr. Ganesh Bala for reviewing and correcting the manuscript and department technicians for their valuable support throughout the study.

Funding: No funding sources

Conflict of interest: None declared

Ethical approval: The study was approved by the Institutional Ethics Committee

\section{REFERENCES}

1. Hiruma-Lima CA, Calvo TR, Rodrigues CM, Andrade FD, Vilegas W, Brito AR. Antiulcerogenic activity of Alchornea castaneaefolia: effects on somatostatin, gastrin and prostaglandin. J Ethnopharmacol. 2006;104(1-2):215-24.

2. Kent-Lioyd KC., Debas HT., Peripheral Regulation of Gastric Acid Secretion. Physiology of the Gastrointestinal Tract. Raven Press, New York: 1994; 1126-1185.

3. Glavin GB, Szabo S. Experimental gastric mucosal injury: laboratory models reveal mechanisms of pathogenesis and new therapeutic strategies. FASEB J. 1992;6(3):825-31.

4. Longo D, Fauci A, Kasper D, Hauser S, Jameson J, Loscalzo J. Harrison's Principles of Internal Medicine. 18th ed. Newyork: McGraw-Hill Professional 2012; 2438.

5. Anoop A, Jegadeesan M. Biochemical studies on the anti-ulcerogenic potential of Hemidesmus indicus R. Br. var. indicus. J Ethnopharmacol. 2003;84(2-3):14956.

6. Warrier PK, Nambiar VPK, Ramankutty C. Indian Medicinal Plants. Orient Longman, Madras. 1994;2: 133-137.

7. Mahanta M, Mukherjee AK. Neutralisation of lethality, myotoxicity and toxic enzymes of Naja kaouthia venom by Mimosa pudica root extracts. J Ethnopharmacol. 2001;75(1):55-60.

8. Care V. CPCSEA guidelines for laboratory animal facility. Ind J Pharmacol. 2003;35:257-74.

9. Kunchandy J, Khanna S, Kulkarni SK. Antiulcer effect of Nigella sativa Linn against gastric ulcers in rats. Arch Int Pharmacodyn. 1985;275:123-38.

10. Ohkawa H, Ohishi N, Yagi K. Assay for lipid peroxides in animal tissues by thiobarbituric acid reaction. Analytical Biochem. 1979;95(2):351-8. 
11. Kakkar P, Das B, Viswanathan PN. A modified spectrophotometric assay of superoxide dismutase. Ind J Biochem Biophys. 1984;21:130-2.

12. Sinha AK. Colorimetric assay of catalase. Analytical Biochem. 1972;47(2):389-94.

13. Tipple TE, Rogers LK. Methods for the determination of plasma or tissue glutathione levels. In: Developmental Toxicol. Humana Press, Totowa, NJ. 2012:315-324

14. Wallace JL, Sharkey KA, Pharmacotherapy of gastric acidity, peptic ulcers, and gastroesophageal reflux disease. In: Nrunton L, Chabner B, Knollman B, eds. Goodman and Gilman's the pharmacological basis of therapeutics, 12th ed. New Delhi: McGraw-Hill publishers 2011: 1547-1565.

15. Rainsford K.D. Mechanisms of gastric contrasted with intestinal damage by non-steroidal anti-inflammatory drugs. In: Rainsford K.D., Velo G.P., eds. Side-Effects of Anti-Inflammatory Drugs. Inflammation and Drug Therapy Series, Springer, Dordrecht; 1987: 2.

16. Goel RK, Bhattacharya SK. Gastroduodenal mucosal defence and mucosal protective agents. Ind J Exp Biol. 1991;29(8):701.

17. Manoharan $P$, Shobana J, Upendarrao G, Thangathirupathi A. Anti-ulcer effect of Coccinia grandis (Linn.) on pylorus ligated (albino) rats. Inter $\mathbf{J}$ Pharma Res Dev. 2010;2(5).

18. Girish C, Vineela S, NarasimhaReddy Y, Reddy OV, Rajasekhar KK, Shankarananth V. Evaluation of Antiulcer Activity of Coccinia grandis Leaves. Res J Pharmacol Pharmacodynamics. 2011;3(2):92-5.

19. Santharam B, Divya V, Thangathirupathi A. Antiulcer activity of ethanolic, aqueous and Total aqueous Extracts of Coccinia grandis Linn. voigt in pyloric ligature induced ulcers in albino rats. International Journal of Pharmacy and Pharmaceutical Sciences 2013; 5(4): 104-6.

20. Tandon R, Khanna RD, Dorababu M, Goel RK. Oxidative stress and antioxidants status in peptic ulcer and gastric carcinoma. Ind $\mathbf{J}$ Physiol Pharmacol. 2004;48(1):115-8.

Cite this article as: Datchanamurty B, Mythireyi D, Divyashanthi CM. Evaluation of antiulcer activity of ethanolic leaf extract of Coccinia grandis in indomethacin induced gastric ulcer model. Int $\mathbf{J}$ Basic Clin Pharmacol 2019;8:629-34. 